\title{
E102チェルノブイリの廃炉への新たな取り組み
}

\section{Initiative for decommissioning of Chernobyl Nuclear Plant}

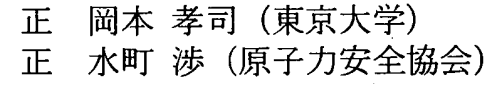

\author{
正 奈良林 直 (北海道大学) \\ ○非 藤井 有蔵（日本エヌ・ユー・エス）
}

Koji OKAMOTO, Tokyo University, 7-3-1 Hongo, Bunkyo-ku, Tokyo

Tadashi NARABAYASHI, Hokkaido University, Kita13jo-Nishi8chome,Kita-ku, Sapporo

Wataru MIZUMACHI, Nuclear Safety Research Assocaition,5-18-7 Shinbashi, Minato-ku, Tokyo

Yuzo FUJI, Japan NUS, 7-5-25 Nishishinjuku, Shinjuku-ku, Tokyo

Construction of the New Safety Confinement (NSC) for the Chernobyl unit 4 started 2010,after about 25years of Chernobyl accident and will complete summer of 2015. This project is being conducted by assistance of EU, USA and other countries including Japan. NSC can cover the whole facility of unit 4, and is installed various components or tools including big bridge crane for decommissioning unit 4 and has durability over 100 years. In addition to construction of NSC, various activities for preparing the decommissioning including developing the technology of monitoring the inside of destructive building and remote access technologies. The spent fuel storage facility and waste proposal facilities are also constructed..

These activities include many valuable information about how to smoothly conduct the decommissioning and it would be important to learn the above activities in conducting the post-processing activities on the Fukushima-Daiichi accident successfully.

Key Words: Chernobyl, New Safe Confinement, Decommissioning, Remote access technology

\section{1. チェルノブイリ原子力発電所の事故 ${ }^{(1)}$}

チェルノブイリ原子力発電所 4 号機は 1986 年 4 月 26 日、不 適切な試験操作で炉心の出力が急上昇し、水蒸気爆発により原子 炉と炉心周辺の構造物の一部が破壊されることにより大量の核 分裂生成物が環境に放出された。燃料は崩壊熱により一旦溶融し た後、周辺のコンクリート構造物等と融合・再凝固し、燃料含有 物質 (FCM : Fuel Containing Materials) といわれるものにな った。また、放出された多量の放射性物質により当時の ソ連を中心に広大な地域が放射性物質で污染されること になった。

\section{2. 当初シェルター(石棺)の建設(2)(3)}

チェルノブイリ事故後、発電所施設の安全確保、放射性物質の 閉じ込め、住民の被ばく低减等について様々な対策が必要となっ た。その中でも原子炬建屋の中に多量の FCM や核分裂生成物 が残っており、これらが建屋外に漏电あるい惴散することを防 止することが重要な対応となった。

チェルノブイリ 4 号機はRBMK というソ連型の黒鉛原子炉で、 もともと格納容器がない原子炉であった。ささらに炉心周辺の構
築物も破壊されたことから、事故後多量の FCM や放射性物質は 環境から隔離されない形で放置された状態となった。

この状態を解消するため 4 号機を囲むシェルター（石棺）が建設 された。シェルターの建設は急を要することから事故後に残っ

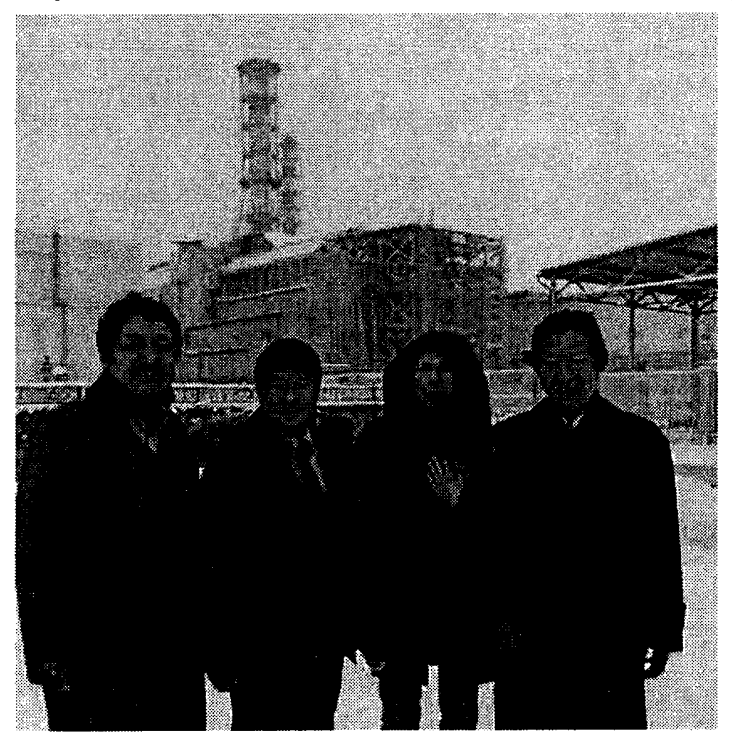

Fig.-1 Original Shelter 
ている建屋の壁を利用し、それ以外に現場で保管されていた資材 等を活用し、事故後6ヶ月程度で建設された。しかしながら、 急ごしらえのため十分な密閉性吕確保されておらず、放射性ダ ストや放射性物質を含む水の流出が心配された。さらに時間経 過とともに劣化が進み、強度や耐久性にも問題があった。図-1 に現在の石棺の概観を示す。チェルノブイリを最終的に廃炉に するためには燃料や放射性物質等の取り出し、設備や機器の解 体・取り出しのための設備が必要であるが、急ごしらえのシェ ルターではこれらの設備を設置するのは難しい状態であった。

\section{3. 廃炬に向けて新シェルターの建設(2)(3)(4)}

3. 1 新シェルターの目的

当初の石棺の問題点を解消し、4号炬全体を力バーし、放射 性物質等の漏洩を防ぐためには、長期にわたって密閉機能を有す る新シェルター（NSC : New Safe Confinement）の建設が喫緊 の課題であった。さらに重要な点としてチェルノブイリ原子力 発電所は廃炬にすることがきめられており、4号炬について本格 的な廃炉を行うためには新シェルターの建設が必須であった。

\section{2 新シェルターの建設計画}

新シェルターの建設は多額の資金と高度の技術が必要なため、 当事国のウクライナだけでは対応が困難であり、西側が資金面、 計画・技術面で協力して行っている。

建設に向けては、1997年に基金が設けられ、2004年 に新シェルターの設計・建設についての入札が実施、2007年 にコンソーシアムの NOVORKA との契約実施、2010年に建 設作業が開始された。

建設費用は検討過程で変更されてきているが、現時点で 1500 億円程度と見込まれる。

\section{3 新シェルターの設計仕様}

新シェルターは鉄骨で組み立てられ、ステンレス板を外面に取 り付けたアーチ状（かまぼこ状）の形状をしている。その仕様は 以下のとおりであり、100年以上にわたって構筑物としての機能 を維持するものとして、換気空調装置等を設置することによりメ ンテナンスを出来るだけ減らせるようにしている（図-2）。

・スパン $-250 \mathrm{~m}$

・長さ $-150 \mathrm{~m}$

•高さ $-110 \mathrm{~m}$

・重量 -30000 トン

・耐久年数 -100 年

新シェルターは現在の石棺を覆うように作られる。これによ り密閉性能を向上させ、雨、風、雪が内部に入らないようにする
とともに、逆に内部の浮遊性及び夜体の放射性物質が環境に放出 されないようにする。

新シェルターは廃炉のための設備を持つことが重要であり、 シェルターのアーチ部に 2 基のブリッジクレーンが設置される 設計となっている。各クレーンは $84 \mathrm{~m}$ スパンのレール上を移動 することができ、以下に示す、さまざまな取替え可能な吊り上げ 工具を取り付けることが出来る。

・一般的な50 トンの吊り上げ能力のもの

・作業員が遮蔽された形で乗ることが出来、50トンの吊り 上げ能力を持つ

・解体に用いるさまざまな可動工具を先端に取り付けるこ とが出来、 $75 \mathrm{~m}$ まで延長が出来る移動可能な機器の台車 を支持する能力を持つ。

シェルターには地震や放射線のモニター機器が設置される。 また、旧ソ連でよく用いられているMSK スケールで6の地震に 耐えられるようになっている。

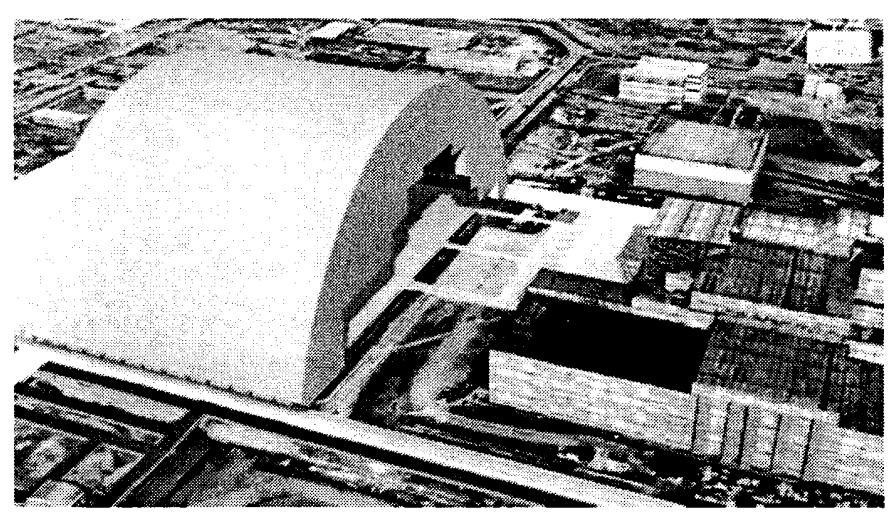

Fig-2 Conceptual picture of NSC

\section{4 新シェルターの建設}

チェルノブイリサイトの 4 号機付近では未だに放射線量が高 いため、新シェルター建設のための作業員の被曝を抑える方法と して、4 号機の炉心から $600 \mathrm{~m}$ はなれた場所の比較的放射線量が 低い場所で新シェルターを組み立て、組み立て後 4 号機の場所に レールを使って移動する方法を採っている。それでもシェルター は高さが $100 \mathrm{~m}$ を超えることから、上部位置では周辺からの放射 線を受けて放射線量は高い值となる。そのため作業員が $30 \mathrm{~m}$ 以 上高いところで作業をしなくても良いような、新シェルターの組 み立て方式が検討された。その結果、新シェルターの上部（第1 セグメント）をまず地上で製作し、それをジャッキアップし、そ の下に次のセグメントを製作していくことを繰り返していく方 式がとられている (図-3)。2012 年 11 月現在で第 1 セグメント (アーチの上部) が $22 \mathrm{~m}$ まで持ち上げられている。 


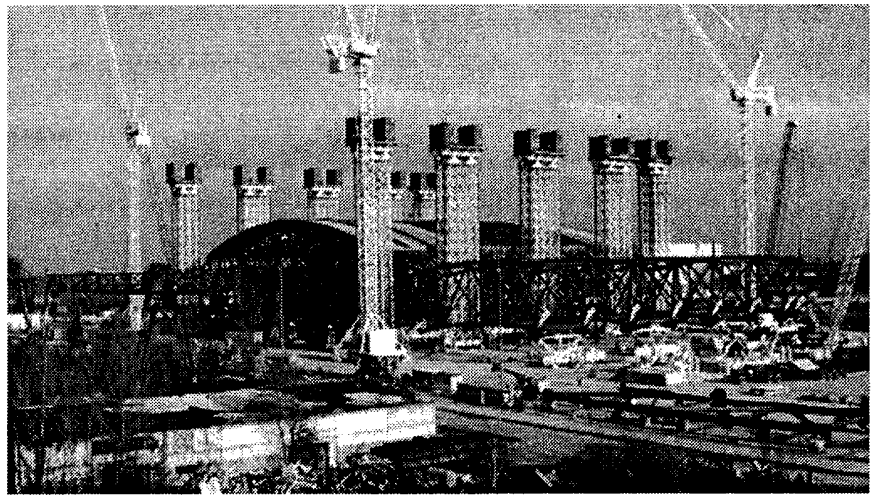

Fig-3 NSC under construction

アーチの組み立てが進んできた段階で内部の機器の取り付け が始まる。最も重要な機器はクレーンであり、これは無線の遠隔 操作方式のものとなっている。クレーンが設置されると新シェル ターは最終場所 (4 号機の位置) ヘとレール上を約 $600 \mathrm{~m}$ 移動す る。構築物の腐食対策については、良く知られているエッフェ ル塔では継絸的に叙装を行っているが、新シェルターでは放射線 の影響がありそのような方法が採れない。そこで、チューブ管の 構造物と上部覆いのステンレス板の間の空調を行い、新シェルタ 一の上部の温度を上げることにより、設備への水の凝縮を防ぎ、 チューブ管の腐食を抑えることが出来るようにしている。

\section{4. 使用済燃料貯蔵施設、放射性廃棄物処理施設 (2) (3)}

事故を起こしたチェルノブイリ 4 号機以外の1-3号機について も今後廃炉措置が進められる。現在チェルノブイリの使用済然料 貯蔵プールで21,000体の使用済燃料が貯蔵されているが、これら の使用済然料は廃炉措置に伴いプールから取り出さなければな らない。そのためチェルノブイリサイトには乾式の第 2 貯蔵施設 が建設されている。

さらに、サイトに土壤、金属、コンクリートなどの中・低レ ベル放射性廃棄物 $\left(50\right.$ 万 $\mathrm{m}^{3}$ 程度)、放射 $\mathrm{s}$ 脳レベルの高い廃棄物 として 2800 t以上のFCM、原子炉、黒鉛、燃料粉應等が存在して おり、900 $\mathrm{m}^{3}$ /年の低レベル液体放射性廃棄物がシェルタ一内か らポンプで排出され、サイトの液体放射性廃棄物処理・貯蔵施設 に移送されている。

これら放射性廃杗物の処理施設についてもこれまで十分なも のとはいえないことから、放射性廃棄物管理システムの 強化策として放射性液体廃棄物処理場、放射性固体廃棄 物総合処理場(図-.4)、長尺スクラップ解体施設等の建設・ 改造が行われている。

放射性廃衰物は、最終的にはこれらの施設に輸送され
た後、処理・処分される。

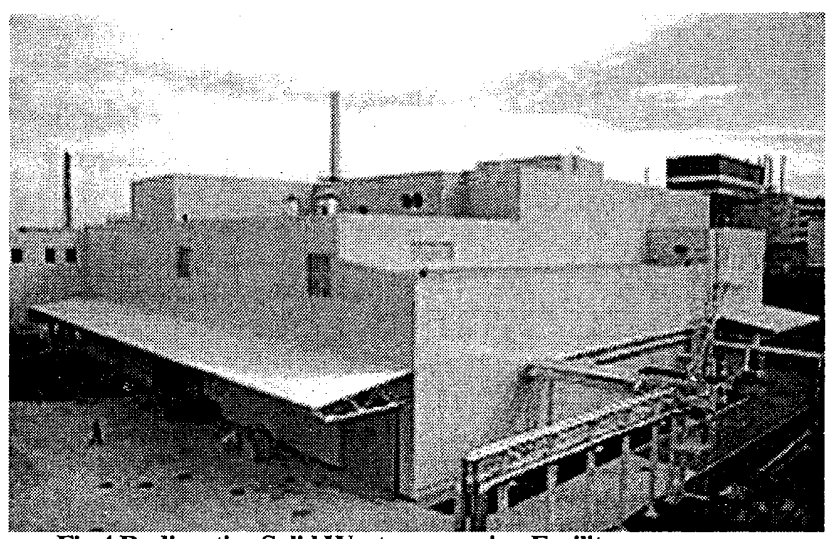

Fig.4 Radioactive Solid Waste processing Facility

\section{5. モニタリング及びロボット技術開発 ${ }^{(2)(3)}$}

4 号機の廃炉を行う場合に炉心晭辺等の内部の状況を十分に確 認した上で設備の解体・運搬を行う必要がある。しかし、4 号機 の内部は長期にわたって放射能レベルが高い状態が続いており、 作業員が立ち入れる状況ではない、そのため廃炉措置を進める中 で内部の状況を確認するための遠隔モニタリング装置の開発や 内部で作業を行うロボティックスの技術開発が重要となってい る。これまでのモニタリングの方法は建屋構造物 (壁等)にボー リングを行い、そこからコアサンプリングを行ったり、ファイバ ースコープによる観察が行われている。ロボットについてはスウ エーデン製の解体ロボット等が使用されており、内部の強い放射 線に長期に耐える装置としてケーブルを利用し、遠隔操作できる 仕組みのものが導入されている。

内部状況のモニタリングのほか現状の石棺からの浮遊性放射 性物質の漏洩状況や敷地での放射線レベルの監視も継続して行 われている。

\section{6. 廃炉に向けてのプロセスでの危険扣制策(2)}

以上チェルノブイリ 4 号機に対寸る新シェルターの建設を中 心にチェルノブイリ原子力発電所での廃炬に向けての取り組み を示したが、これらの対応プロセスで作業員、住民、環境を潜在 的な核的な面、放射能面での危険から防護することが重要である。 そのためチェルノブイリでは(優先プロジェクト研究の実施、 (2)原発事故の影響軽减、(3)作業員と自然環境の安全性向上、(4)原 発事故後の現場を環境的に安全なレベルに改善の 4 方針を定め、 それぞれの方針に対寸る具体的措置が明確化し、それに基づく対 応を行っている(図-5)。 
7. 福島第一の廃炉作業への反映

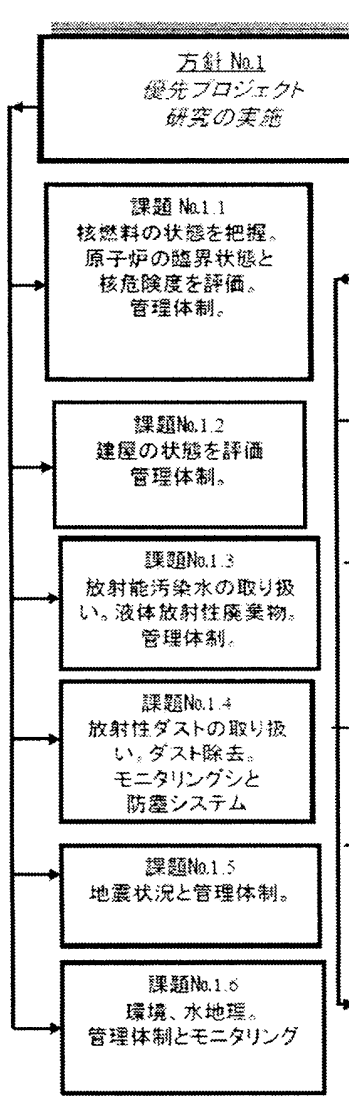

参考文献

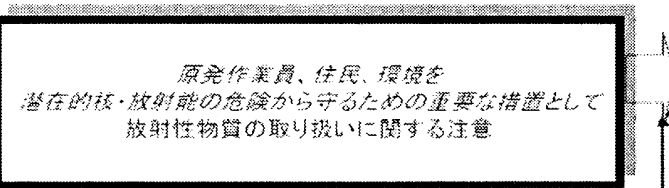

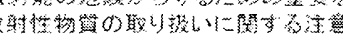

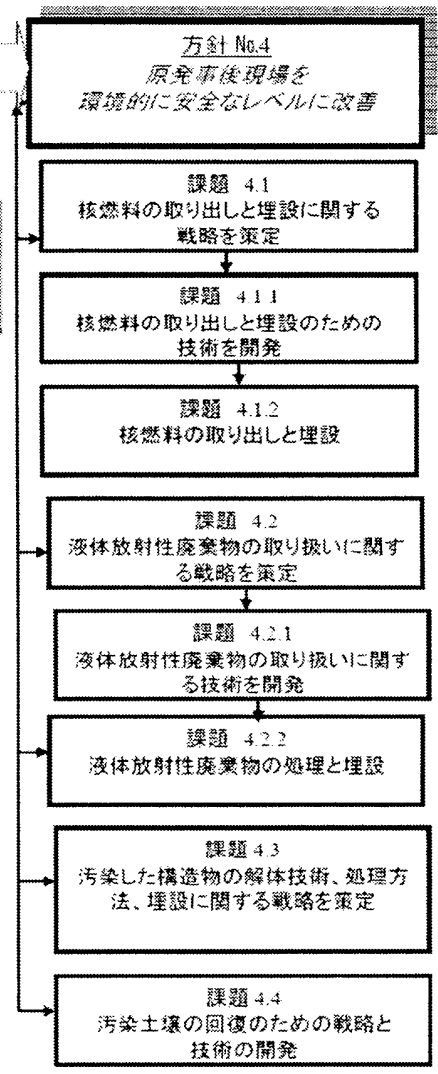

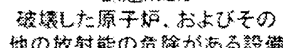

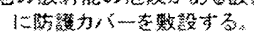
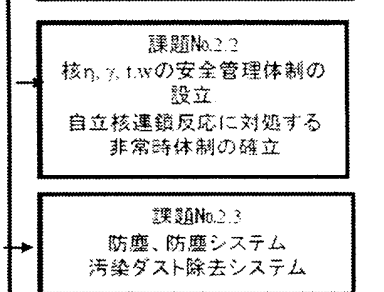

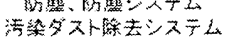

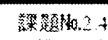

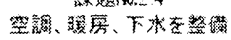

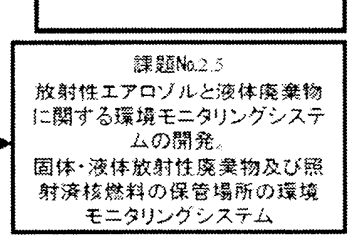

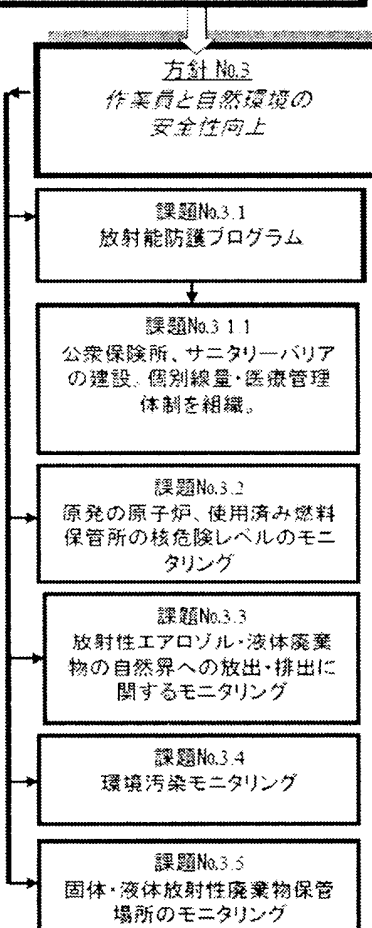

Fig.5 Strategy for protecting the personnel, people and environment from the nuclear and Radiation risk

福島第一においても廃炉に向けて作業が進んでいるが、チェル ノブイリの廃炉対応は福島第一の対応の少し前を進んでいる部 分も多いと考えられる。チェルノブイリの対応では、新シェル夕 一の建設及び長期にわたつての設備の機能維持方策、廃炉対応機 器の開発、作業員の被曝低限方策、廃炉計画の方針と手順明確化 等について積極的な対応が行われており、今後の福島第一の廃炉 にむけての検討の参考になる部分が多くあると考えられる。
(1) 昭和 61 年 原子力安全年報 原子力安全委員会 第 1 編 ソ連原子力発電所事故 昭和 61 年 12 月

(2)1986 年チェルノブイリ原子力発電所 (旧ソ連) 事故から学ぶ 3.11 後処理戦略了日本機械学会動力エネルギーシステム部門原子 力の安全規制の最適化に関する研究会シンポジウム 2012

(3)Twenty-five Years after Chernobyl Accident: Safety for the Future National Report of Ukraine 2011

(4)Building Chernobyil's New Safe Confinement http://www.theengineer.co.uk/in-depth/the-big-story/building-chernobyl s-new-safe-confinement/1015479.article 